\title{
The in vivo efficacy of highly porous carbon nanocomposites prepared from sugar beet waste for the Ochratoxin A detoxification
}

\author{
Muhammad Zahoor ${ }^{1 *}$, Naila Gulfam², Muhammad Khisroon ${ }^{2}$, \\ and Farhat Ali Khan ${ }^{3}$ \\ ${ }^{\text {I} D e p a r t m e n t ~ o f ~ C h e m i s t r y, ~ U n i v e r s i t y ~ o f ~ M a l a k a n d, ~ C h a k d a r a, ~ D i r ~ L o w e r, ~} 18800$ KPK, Pakistan \\ ${ }^{2}$ Department of Zoology, Peshawar University, Khyber Pakhtunkhwa, Pakistan \\ ${ }^{3}$ Principal Abbotabad international college of pharmacy AIMI, Abbotabad, KPK, Pakistan
}

\begin{abstract}
ZAHOOR, M., N. GULFAM, M. KHISROON, F. A. KHAN: The in vivo efficacy of highly porous carbon nanocomposites prepared from sugar beet waste for the Ochratoxin A detoxification. Vet. arhiv 89, 851-872, 2019.
\end{abstract}

ABSTRACT

The aim of this study was to develop highly porous carbon nanocomposites for detoxification of ochratoxin A (OTA) in broilers. One-day-old chicks were divided into six groups (A to F). Group A was given pure feed. Group B was given $400 \mu \mathrm{g} / \mathrm{kg}$ of OTA contaminated feed, while the rest of the groups were fed on $400 \mu \mathrm{g} /$ $\mathrm{kg}$ of OTA contaminated feed plus a different level of the adsorbent. The clinical signs of the positive control (group B) such as depression, diarrhea, increased water intake, low body weight, a high degree of genotoxicity, and swollen and hemorrhagic kidneys and liver, were compared with the other groups. In group B chicks, the serum ALT (alanine transferase), ALP (alkaline phosphatase), creatinine and urea levels were significantly higher, while albumin, globulin and total proteins levels were significantly lower than in negative control group A. The adsorbent treated groups showed almost normal clinical signs. Group $\mathrm{C}$ and D were affected to some extent, however, groups E and F showed undamaged DNA, normal behavior and blood biochemistry, and wellmaintained histological structure, like that of the negative control group.

Key words: broiler chicken; ochratoxin A; adsorbent; blood biochemistry; ALT; ALP

\section{Introduction}

Contamination of poultry feed by fungi and their toxic products (mycotoxins) is one of the major threats to the poultry industry which negatively affects the nutritional and organoleptic properties of feed (KUIPER-GOODMAN and SCOTT, 1989; FINKGREMMELS, 2004). Certain species of aspergillus and penicillium (A. flavus, A. niger,

\footnotetext{
${ }^{*}$ Corresponding author:

Dr. M. Zahoor, Department of Chemistry, University of Malakand Chakdara Dir Lower KPK, Pakistan, E-mail: mohammadzahoorus@yahoo.com
} 
A. carbonarius, A. ochraceus, and P. verrucosum) produce ochratoxins in poultry feed. There are three classes of ochratoxins: ochratoxin A, B, and C. The toxicity brought about by ochratoxin A (OTA) in the experimental animals is more frequent and severe than the other two (MURPHY et al., 2006).

The high morbidity and mortality rates in chicks due to the ingestion of OTA contaminated feed lead to excessive financial losses (OGUZ et al., 2003). Besides, OTA also hampers weight gain, food conversion ratio, egg-producing efficiency and feed intake in poultry (ORTATATLI et al., 2005). It increases the severity of certain pathological conditions such as salmonellosis, Marek's disease, coccidiosis and aspergillosis (IBRAHIM et al., 2000). Pathomorphological, immune and serum biochemical alterations also occur due to OTA ingestion (KOYNARSKI et al., 2007). It has been observed that ochratoxin A causes dehydration, restlessness and emaciation, occasionally accompanied by diarrhea (SAWALE et al., 2009). Poultry fed on OTA contaminated feed have low levels of immunoglobulins and impaired complementary activities. Atrophy of the lymphoid organs, as well as reduction of lymphocytes have also been observed by several researchers (STOEV et al., 2000). Comparable outcomes regarding poor FCR (food conversion ratio), increased mortality, increased relative kidney weight and decreased body weight have also been described by various researchers (IBRAHIM et al., 2000; KOYNARSKI et al., 2007; KHAN and ZAHOOR, 2014). A number of other complications, such as nephrotoxicity, hepatotoxicity, genotoxicity, and carcinogenicity (SCHILTER et al., 2005), have been observed in birds fed with ochratoxin A contaminated feed.

In the past few decades, various chemical, physical and biological treatments have been used for detoxification of ochratoxins. Amongst them, adsorption is the most effective method (MEDINA et al., 2007). Activated carbon, due to its high surface area, is a widely used adsorbent for such purposes. However, the recovery of activated carbon from feces is not an easy task. To overcome this, the activated carbon is magnetized by depositing iron oxide over it. The resulting magnetic activated carbon can effectively be removed from slurry after use through magnetic processes. In our previous work, we used magnetic carbon nanocomposites for detoxification of mycotoxins in vitro. However, the deposition of iron oxide on activated carbon reduces the surface area (KHAN and ZAHOOR, 2014 ; ZAHOOR and KHAN, 2016; GULFAM et al., 2018).

The aim of the present study was to prepare highly porous magnetic carbon nanocomposites from biomass and use them for detoxification of ochratoxin $\mathrm{A}$ in the gastrointestinal tract of Gallus gallus domesticus. 


\section{Materials and methods}

Preparation and characterization of the highly porous, carbon-based nanocomposites. The highly porous, magnetic nanocomposites were prepared following the methods of KHAN and ZAHOOR (2014) with slight modifications. Sugar beet waste was used as biomass precursor for preparation of the carbon-based adsorbent. The material was crushed and soaked in ethanolic $\mathrm{FeCl}_{3} .6 \mathrm{H} 2 \mathrm{O}(10 \% \mathrm{w} / \mathrm{v})$ for half an hour. The biomass was then taken out and dried at room temperature for about $24 \mathrm{~h}$. The dried material was then placed in an oven for drying at $100{ }^{\circ} \mathrm{C}$ for $5 \mathrm{~h}$. The dried mass was then charred in a specially designed chamber, consisting of a stainless steel container comprising an electric heater, wire gauze, an inlet and an exhaust outlet, and a supply of nitrogen gas (to provide an inert environment). The temperature in the chamber was $500{ }^{\circ} \mathrm{C}$, which was set in such a manner that there was a $10{ }^{\circ} \mathrm{C}$ increase in temperature/min. The partially treated material was kept in the chamber for $2 \mathrm{~h}$ to accomplish the process. The processed sample was then subjected to a magnetic bar to confirm whether it was magnetic or not. All the sample contents stuck to the magnet, indicating the magnetic character of the resulting material. In order to enhance the surface area of the resulting composite,

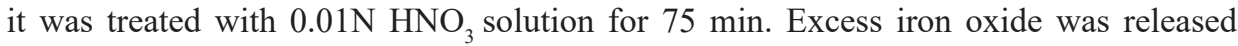
from the composite by acid. The prepared adsorbent was then characterized by different instrumental techniques, such as Surface Area Analyzer, FTIR (Fourier Transform Infrared Spectroscopy), SEM (Scanning Electron Microscopy), XRD (X-Ray Diffraction), TG/ DTA (Thermogravimetric and Differential Thermal Analysis), EDX (Energy Dispersive X-Ray Spectroscopy) etc.

Induction of ochratoxin $A$ in broilers. A total of 600, one-day old broiler chicks (Gallus gallus domesticus) were purchased from a local hatchery, Rawalpindi, Pakistan and reared in well-managed and hygienic conditions. All these chicks were divided into six equal groups (A-F) having 100 chicks in each group. Chicks in group A were provided with an ochratoxin A free diet throughout the experiment (negative control). Chicks in group B were provided with ochratoxin A $(400 \mu \mathrm{g} / \mathrm{kg})$ contaminated feed (positive control). Chicks in groups C, D, E, and F were kept on ochratoxin A $(400 \mu \mathrm{g} / \mathrm{kg})$ contaminated feed mixed with $0.3,6,9$ and $1.2 \%$ of the prepared adsorbent, respectively. All the experiments and overall handling of the animals were performed in accordance to the guidelines of the Pakistan Ethics Committee for Animal Care \& Use, and ARRIVE guidelines. Approval was obtained from the animal ethics committee of the University of Malakand (UOM/ethics.com/Biochem. 02).

Different physical and biochemical parameters, such as genotoxicity, histopathology, gross lesions, organ enlargement, total body weight, organ weight, mortality and clinical signs of the chicks were noted at the end of each week ( 6 weeks). The blood serum 
biochemistry of the chicks was investigated by slaughtering three individual chicks from each group at the end of the $1^{\text {st }}$ to $6^{\text {th }}$ weeks of the experiment.

Comet assay. The genotoxic effect of OTA was determined through comet assay following the protocols of SINGH et al. (1988 and 1990) with slight modifications. The blood samples were collected in $5 \mathrm{~mL}$ sterilized syringes from the brachial vein of the selected chicks. For testing genotoxicity in the kidney and liver, about $1 \mathrm{~g}$ tissue were homogenized and mixed with about 5-6 mL of PBS (Phosphate Buffer Saline). On a single coated slide, $75 \mu \mathrm{L}$ of LMPA (Low Melting Point Agarose, 1.5\%) was mixed with $15 \mu \mathrm{L}$ of blood. A cover slip was placed on it and the slide was put on an ice pack for 5 to 10 min. The coverslip was removed and again $85 \mu \mathrm{L}$ LMPA was deposited on the same slide and a coverslip was placed on it again. After $10 \mathrm{~min}$, the coverslip was removed and the slides were shifted to a freshly prepared lysing solution, poured in a glass tray, overnight at $4{ }^{\circ} \mathrm{C}$. After electrophoresis, the slides were rinsed with neutralization buffer and stained with $70 \mu \mathrm{L}$ DNA specific fluorescent dye acridine orange $(20 \mu \mathrm{g} / \mathrm{mL})$. Before observing the slides, the excess water on the edges and back of the slides was blotted away. From every slide, 100 cells were randomly selected, and images were taken at 400x using a fluorescent microscope (Nikon Eclipse 80 i) equipped with an excitation filter of 450-490 nm. Comet tail lengths (consisting of nuclear region and tail) were scored visually into 5 comet classes (Fig. 1): comet class 0 (no damage, hence no tail), comet class 1 (tail up to 1.5 times the diameter of the comet nucleus), comet class 2 (tail 1.5-2.0 times the diameter of the comet nucleus), comet class 3 (tail 2.0-2.5 times the diameter of the comet nucleus) and comet class 4 (maximally damaged with total DNA in its tail).

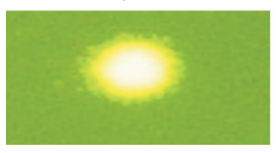

Class 0

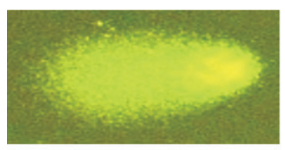

Class 3

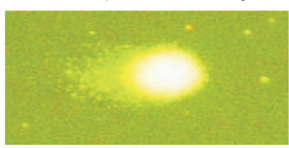

Class 1

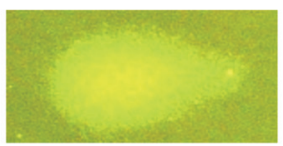

Class 4

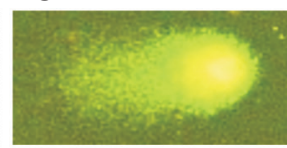

Class 2

Fig. 1. Different comet classes (0-4) and level of DNA damage

A final overall total comet score for all 100 cells was obtained by adding up the number of cells in each class, times the class number, giving a rating between $0-4$ (COLLINS, 2004):

$\mathrm{TCS}=0(\mathrm{n})+1(\mathrm{n})+2(\mathrm{n})+3(\mathrm{n})+4(\mathrm{n})$

where $n$ indicates the number of cells in each class. 
Histological analysis. For histological evaluation, the tissues samples were prepared manually as described by PROPHET et al. (1992). Kidney and liver samples of selected broiler chicks were immediately transferred to $10 \%$ neutrally buffered formalin and then placed in fixative for $48 \mathrm{~h}$. These tissues were then dehydrated in concentrated ethanol solutions. Finally, they were transferred to a clearing solution. The dehydrated and cleared tissues were infiltrated with melted paraffin and embedded in a stainless steel mold. The molds were then placed in a freezer to solidify, after which the tissue blocks were removed. The tissues were sectioned through a rotary microtome, and stained with Harris hematoxylin and eosin-phloxine solution. Photographs of tissues sections were taken on a digital camera attached to the microscope.

Blood serum biochemistry. Serum biochemical parameters such as alanine transferase (ALT), serum alkaline phosphatase (ALP), serum albumin, total proteins, globulin, serum urea, and creatinine, were determined using commercially available kits by RANDOX.

Clinical signs and behavior. Clinical signs and the behavior of poultry chicks (attentiveness, attraction to water and feed, and consistency of feces) were recorded in the form of scores from 0 to 3 . Where $0=$ absence, $1=$ minor, $2=$ average and $3=$ extreme (degree of the parameters studied). The observations were recorded at the end of each week.

\section{Results}

Highly porous magnetic adsorbent. The prepared magnetic adsorbent exhibited a Langmuir surface area of $989.12 \mathrm{~m}^{2} / \mathrm{g}$ and $50 \%$ magnetic character.

SEM, XRD, EDX, TG/DTA and FTIR photographs of the highly porous carbon nanocomposite are presented in Fig. 2. The SEM picture demonstrates the honeycomblike porous surface. This confirms the detachment of excess iron oxide after treating with $\mathrm{HNO}_{3}$ solution. The white patches/dots in the SEM photographs confirms the presence of iron oxide. The novel adsorbent was then used for the in vivo detoxification of ochratoxin A.

Ochratoxin A induced DNA damage and its detoxification in broilers. Blood, kidney and liver samples of chicks were analyzed (group A-F) to estimate the degree of DNA damage caused by ochratoxin A. The samples of group B and C showed a higher frequency of total comet score and comet class per 100 cells compared with groups A, $\mathrm{E}$, and F throughout the experimental period. The value of the TCS of blood samples of chickens in group A (negative control) was $25.27 \pm 4.8$ while that of the chickens in group B (positive control) was $221.9 \pm 9$. Throughout the experiment, the blood samples of broilers in group A (negative control) showed a maximum score of 0 and a minimum score of 4 . The value of the TCS of groups C and D at the end of the $6^{\text {th }}$ week was $76.64 \pm$ 8.5 and $65.29 \pm 8.6$ respectively. Groups E and F showed TCS of $42.96 \pm 7.6$ and $28.94 \pm$ 5.2 respectively at the end of the $6^{\text {th }}$ week. The least TCS was shown by groups A, F, and 
M. Zahoor et al.: Ochratoxin A detoxification by highly porous carbon nanocomposites

$\mathrm{E}$, and the highest by group B, followed by $\mathrm{C}$, indicating that maximum DNA damage had taken place in group B. The TCS for blood samples at the end of the experimental period was in the following order: group $\mathrm{B}>\mathrm{C}>\mathrm{D}>\mathrm{E}>\mathrm{F}>\mathrm{A}$.

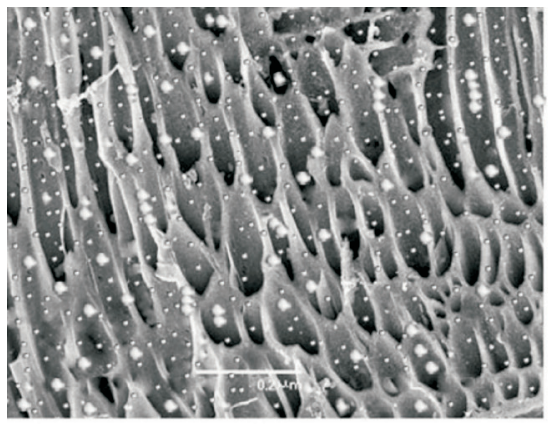

SEM

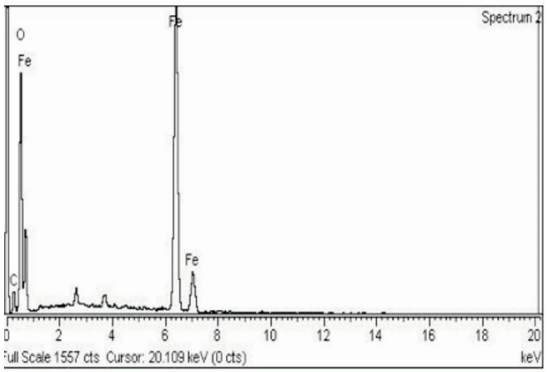

$E D X$

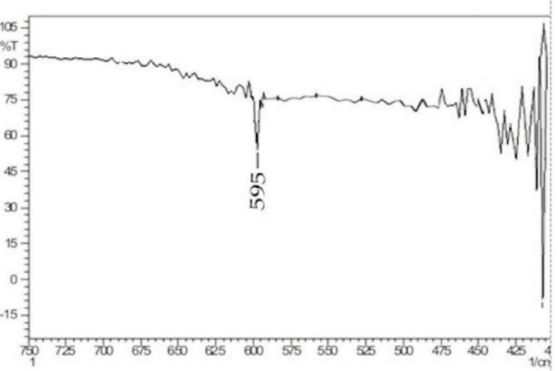

FTIR spectra

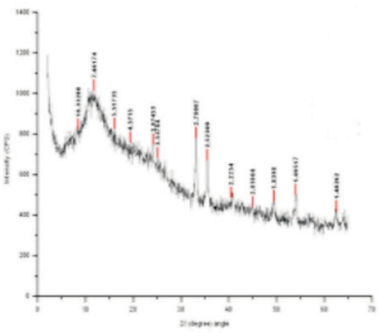

XRD

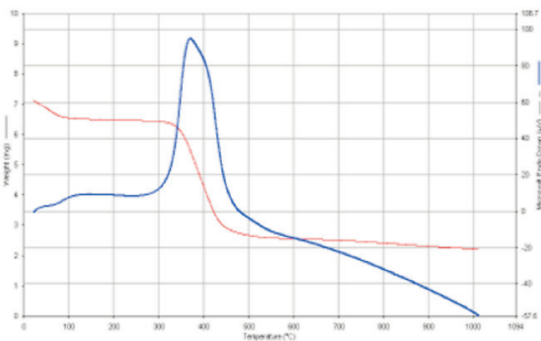

$T G / D T A$

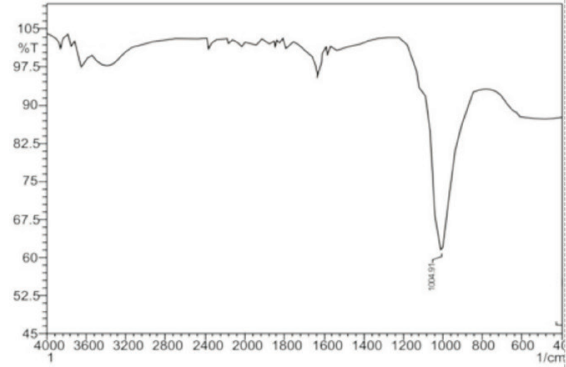

FTIR spectra

Fig. 2. characterization of the highly porous carbon nanocomposite derived from sugar beet waste 
Similarly, liver samples of broilers of group A showed the lowest TCS value of 27.3 \pm 4.9 . Groups B and C showed TCS of $225.99 \pm 6.1$ and $81.3 \pm 11.6$, respectively, while the TCS values of groups D, E, and F were; $65.63 \pm 173,44.3 \pm 6.4$ and $28.94 \pm 5.2$, respectively. Here also a high degree of DNA damage was recorded in the liver sample of groups B and C. For the liver samples, the TCS was in following order: group B $>$ C $>$ D $>$ E $>$ F $>$ A.

For kidney samples, the TCS at the end of the experiment was in the order: group B $>\mathrm{C}>\mathrm{D}>\mathrm{E}>\mathrm{F}>\mathrm{A}$. Group A showed the minimum value of TCS $28.66 \pm 6.1$, for group $B$ it was $235.64 \pm 7.9$, while for groups $C$ and $D$ the values were $82.17 \pm 5.6$ and $66.96 \pm$ 8.6, respectively. Groups E and F exhibited low TCS values of $44.31 \pm 3.4$ and $32.32 \pm$ 4.7 , respectively. The highest total comet score was observed for group B. The organ wise TCS was in the order: kidney $>$ liver $>$ blood.

Histopathology of broilers. The histopathological observations of the kidneys and livers ( $\left(1^{\text {st }}\right.$ week to $6^{\text {th }}$ week) are presented in Figs 3 and 4 . A normal histological pattern for the kidneys and livers was presented by the chicks in group A throughout the experimental period. Kidney samples of group B were marked by a mild degree of degenerative changes at the end of the second and third weeks of the experiment. The pathological effect of ochratoxin A was prominent at the end of the $4^{\text {th }}$ week and even more severe at the end of the $6^{\text {th }}$ week. The renal tubules of the kidney showed extreme congestion, which led to the complete blockage of the lumen. Excessive proliferation was presented by the epithelial cells in the glomeruli, with a maximum degree of hyalinization. Blood vessel congestion was also found in the parenchyma layer. Thickened bowman capsules were also observed, along with dilated urinary spaces (which were more severe at the end of the experimental period). Likewise, maximum pathological changes were also observed in several sections of the liver during the last week of the experimental period. These changes included the acute cloudy type of cell swelling, and congestion of hepatocytes throughout the hepatic parenchyma. Lobular denegation was also observed at several points. Individual cell necrosis was indicated by pyknotic nuclei in the hepatocytes. The sinusoidal spaces were reduced to a great extent due to cell swelling. Pericapillary edema, as well as perivascular mononuclear cell infiltration, were observed in group B chicks and became severe at the end of the $6^{\text {th }}$ week. Chickens in groups $\mathrm{C}, \mathrm{D}, \mathrm{E}$, and $\mathrm{F}$ did not show any alterations from the normal histological pattern during the first week of the experimental period. Normal histological patterns of the liver were shown by these groups during the initial two weeks of the experimental period. Chicks in groups $\mathrm{C}$ and D showed a mild form of pathological changes at the end of the third and fourth weeks. These pathological changes were: thickening of the bowmen's capsules and slight congestion in the epithelial cells of the renal tubules. No such pathological changes were observed in the kidneys and livers of chicks in groups $\mathrm{E}$ and $\mathrm{F}$. 
M. Zahoor et al.: Ochratoxin A detoxification by highly porous carbon nanocomposites

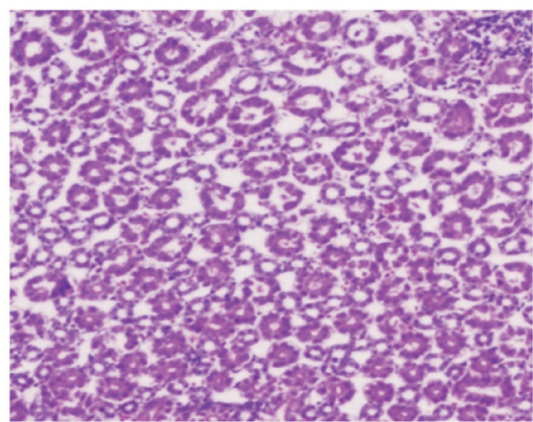

A

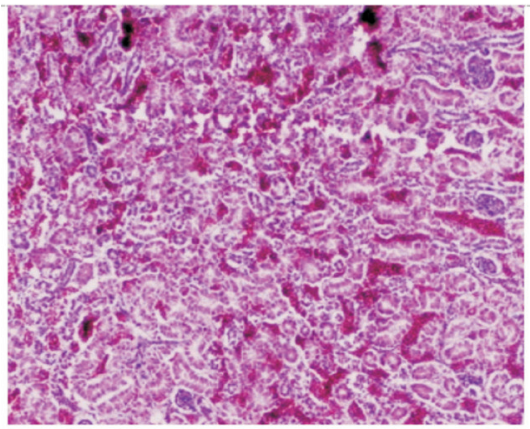

B

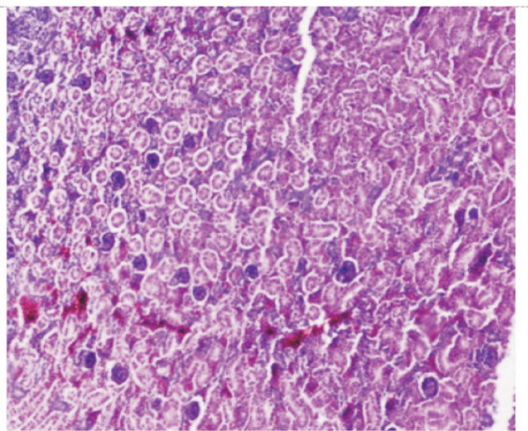

C

Fig. 3. Photomicrographs showing the histopathology of the kidneys of different groups of chickens at 42 days of age, at two different magnifications. 
M. Zahoor et al.: Ochratoxin A detoxification by highly porous carbon nanocomposites
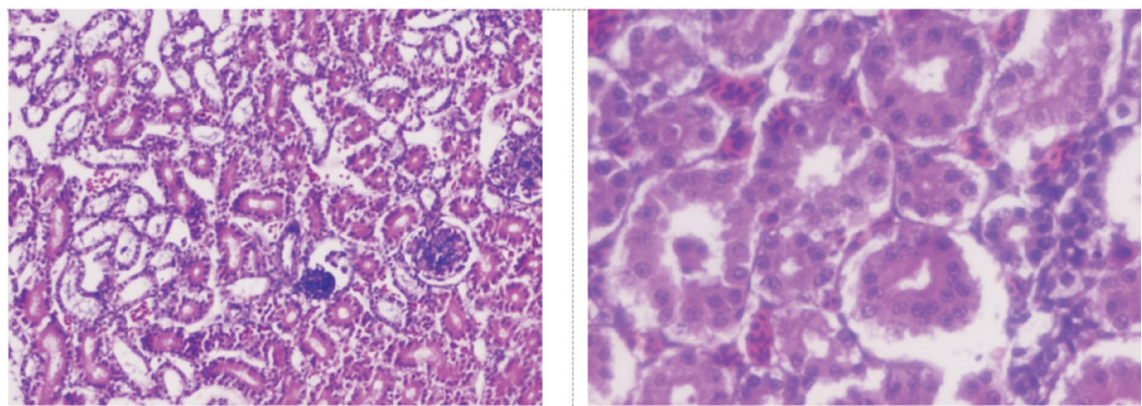

D

D
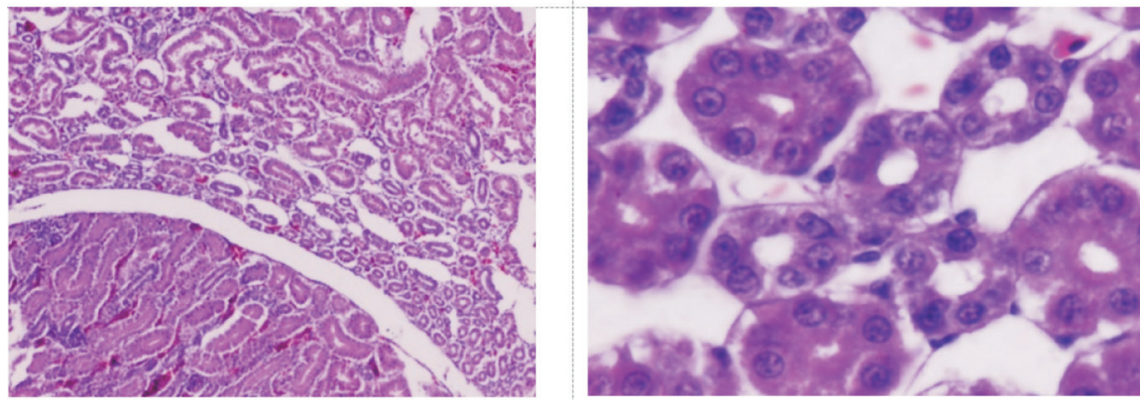

$\mathbf{E}$

$\mathbf{E}$

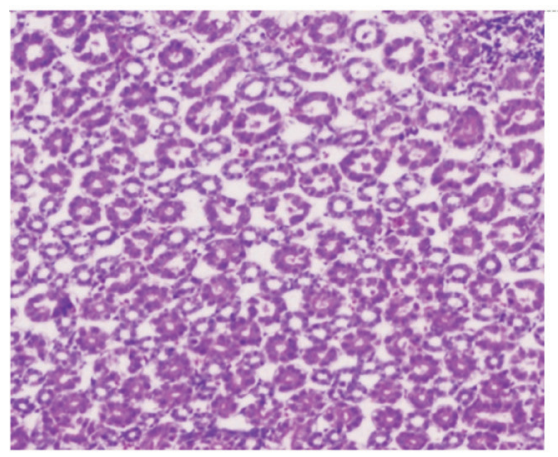

F

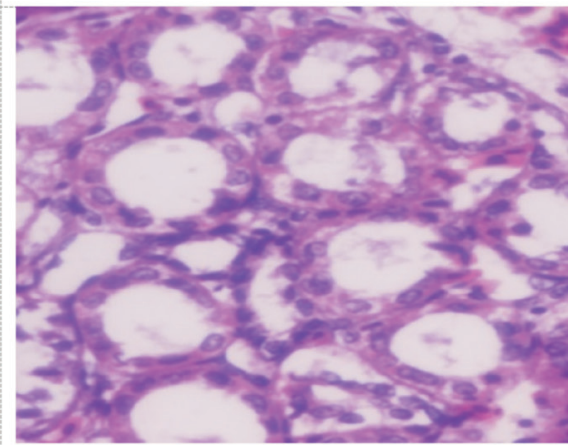

F

Fig. 3. Photomicrographs showing the histopathology of the kidneys of different groups of chickens at 42 days of age, at two different magnifications (continued). 
M. Zahoor et al.: Ochratoxin A detoxification by highly porous carbon nanocomposites
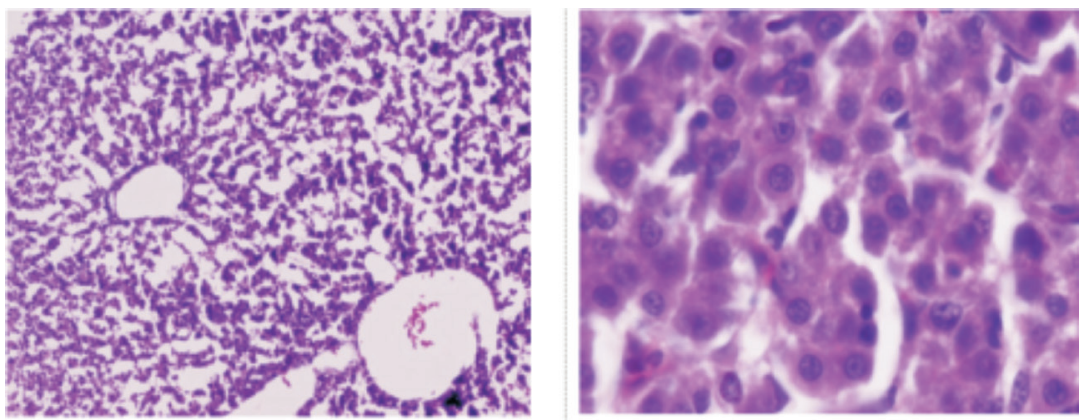

A

A
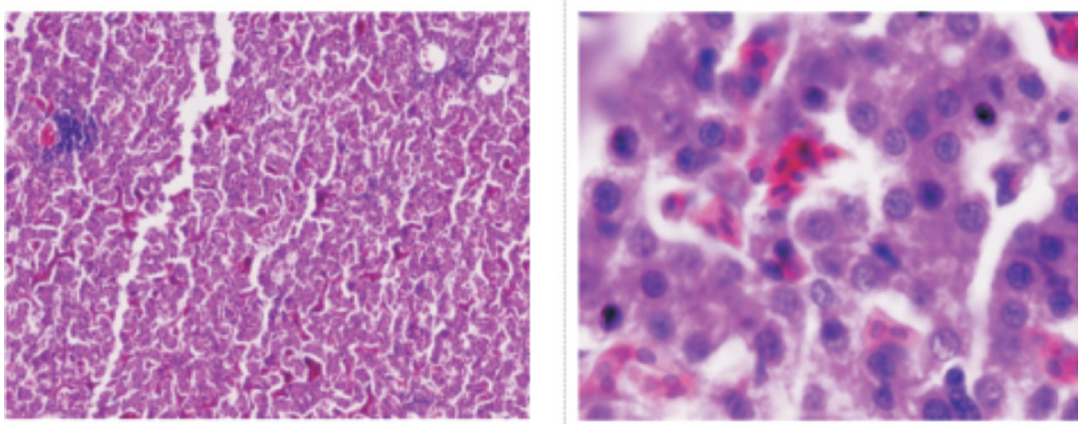

B

B
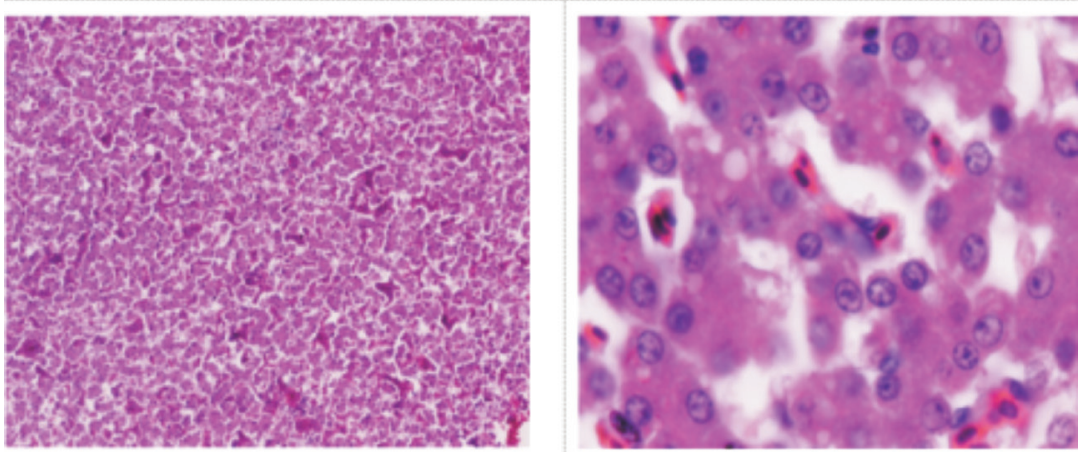

C

C

Fig. 4. Photomicrographs showing the histopathology of the livers of different groups of chickens at 42 days of age, at two different magnifications. 
M. Zahoor et al.: Ochratoxin A detoxification by highly porous carbon nanocomposites
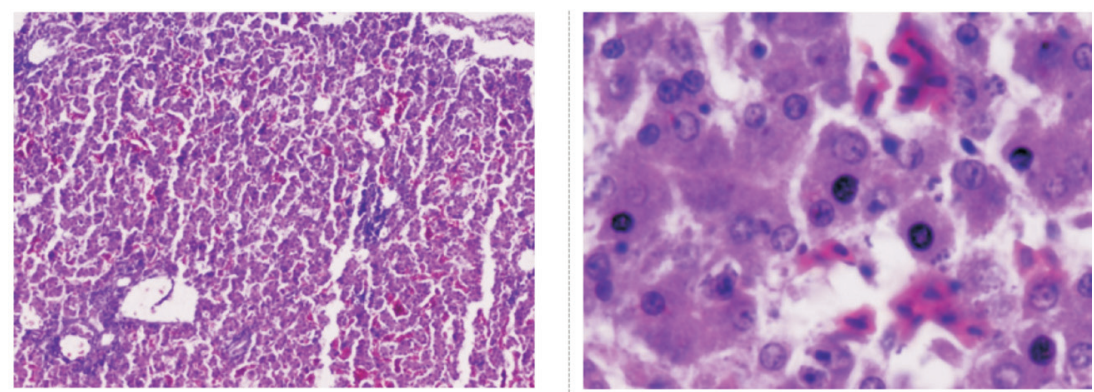

$\mathrm{D}$

$\mathrm{D}$
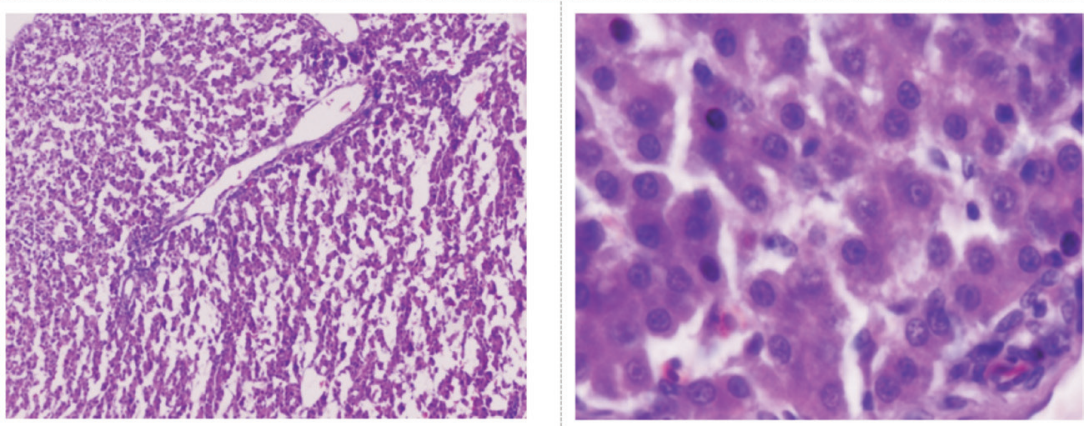

E

$\mathrm{E}$

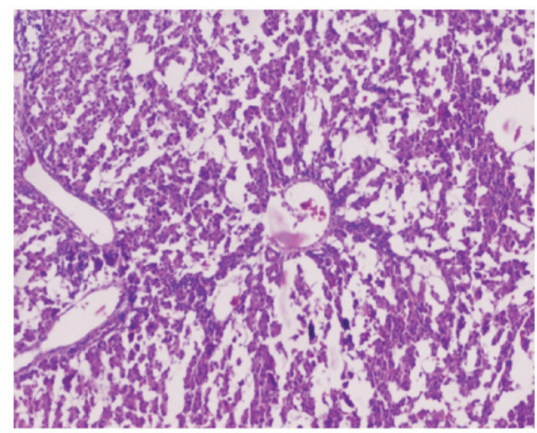

F

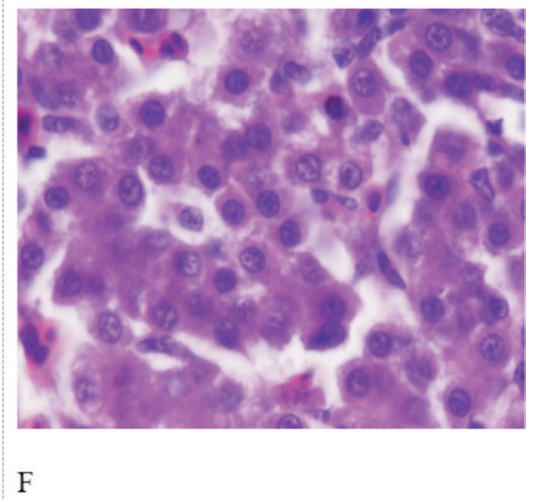

Fig. 4. Photomicrographs showing the histopathology of the livers of different groups of chickens at 42 days of age, at two different magnifications (continued). 
A moderate degree of congestion was observed in chicks in groups $\mathrm{C}$ and $\mathrm{D}$ at the end of the $5^{\text {th }}$ and $6^{\text {th }}$ weeks of the experiment. Moreover, pyknotic nuclei in the tubular epithelial cells of kidney were also prominent, and proliferation of the epithelial cells in the glomeruli had resulted in reduced urinary spaces. Likewise, liver sections of groups $\mathrm{C}$ and $\mathrm{D}$ presented cellular infiltration of a mild degree around the blood vessels. Individual hepatocytic necrosis and cloudy swelling of a moderate degree were also observed, which resulted in a slight reduction of the sinusoidal spaces. The mildness of the histopathological changes in groups $\mathrm{C}$ and $\mathrm{D}$, when compared to group $\mathrm{B}$ (positive control) was due to the fact that some of the ochratoxin A had been adsorbed by the magnetic nanocomposites in the GIT.

Gross lesions in different organs. Groups A and F showed normal morphology of different organs; no lesions and hemorrhages were observed in the kidneys, liver, or heart. On the other hand, group B showed gross lesions in the kidneys and liver. Gross lesions in the kidneys started from the $2^{\text {nd }}$ week and in the liver in the $3^{\text {rd }}$ week. The severity increased day by day and reached its maximum at the end of the $6^{\text {th }}$ week of the experiment. In group $\mathrm{C}$, minor lesions began in the kidney in the $3^{\text {rd }}$ week and remained intact until the end of the $6^{\text {th }}$ week, while a mild lesion of the liver was noted at the end of the $4^{\text {th }}$ week and was intact until the end of the experimental period. In groups D and $\mathrm{E}$, lesions were recorded in very few birds at the end of the last week of the experiment.

The frequency of lesions in the kidney and liver (Figs 5 and 6) was high for group B, while for the adsorbent treated groups (D, E, and F) normal morphological patterns were observed.

Body weight of broilers. The relative body weight of chickens in group B, fed on toxin contaminated feed throughout the experimental period, was significantly lower than the rest of the groups. In group $\mathrm{F}$ the relative body weight of chicks was significantly higher than that of groups $\mathrm{C}$ and $\mathrm{D}$, fed on ochratoxin $\mathrm{A}$ and different levels of adsorbent, at the end of the $3^{\text {rd }}$ week. No significant differences were observed in the body weight of the birds in groups $\mathrm{E}$ and $\mathrm{F}$. However, the relative body weights of group $\mathrm{B}$ and $\mathrm{C}$ chicks were significantly lower than those of groups A, E and F at the end of the $5^{\text {th }}$ and $6^{\text {th }}$ weeks.

Organ weight of broilers. The results of the relative weights of the kidneys, liver and spleen show that there were no significant differences between groups A, E and F at the end of the first week. However, significant differences were observed in the case of group B as compared to the other groups. In group B, the increased weight of the kidneys, liver and spleen were observed. The results of the relative weight of the bursa of fabricius showed that the difference in the values in the case of groups $\mathrm{A}, \mathrm{E}$ and $\mathrm{F}$ were non-significant at the end of the $1^{\text {st }}$ week, while the values of group B were significantly lower than the other groups at the end of the $2^{\text {nd }}$ to $6^{\text {th }}$ weeks. 
M. Zahoor et al.: Ochratoxin A detoxification by highly porous carbon nanocomposites
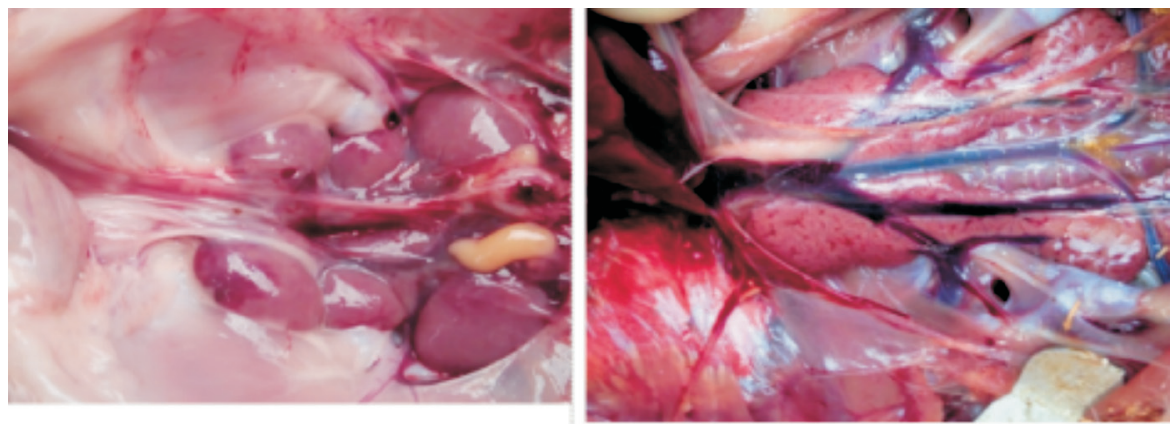

A

B
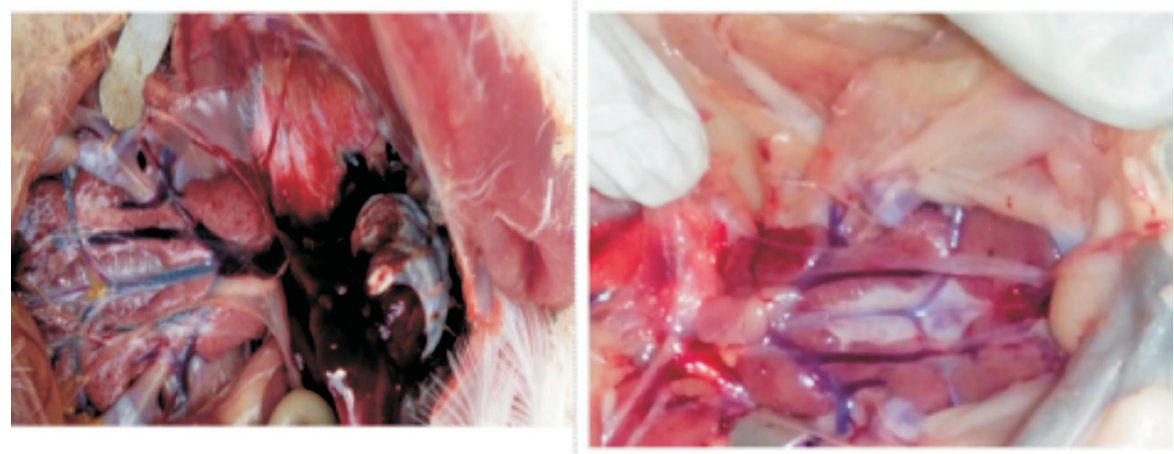

C

D
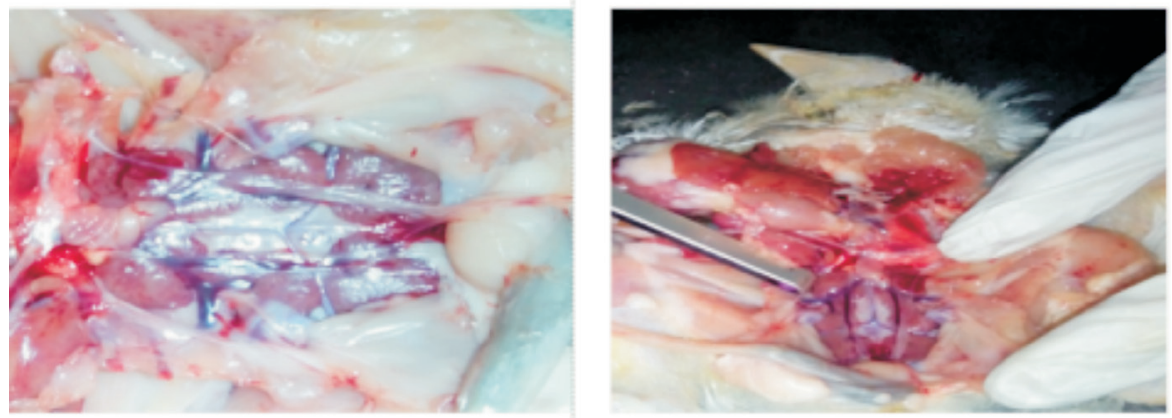

E

F

Fig. 5. Photomicrographs showing kidney lesions in different groups

Vet. arhiv 89 (6), 851-872, 2019 
M. Zahoor et al.: Ochratoxin A detoxification by highly porous carbon nanocomposites
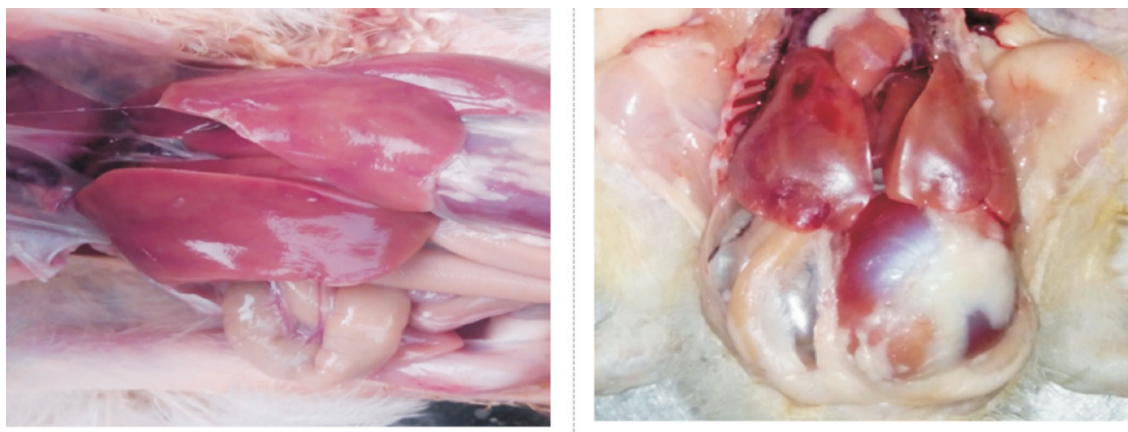

A

B
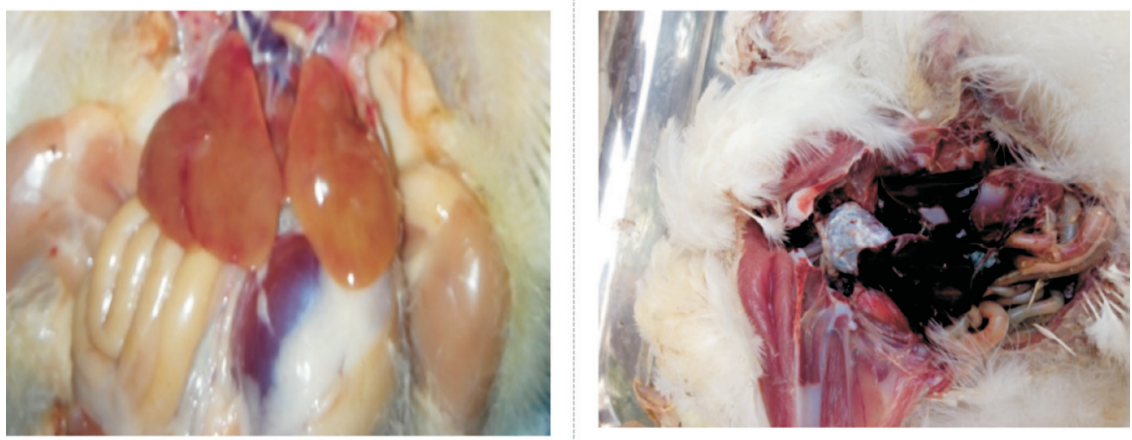

C

$\mathrm{D}$

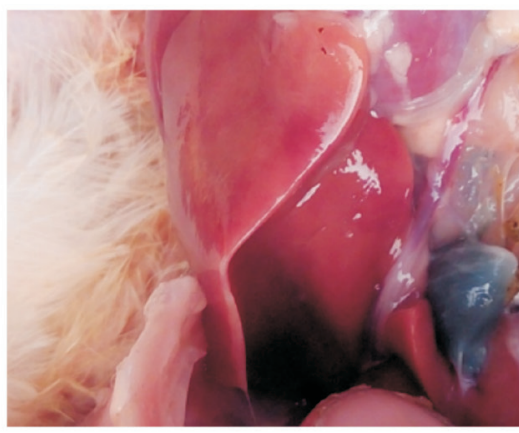

$\mathrm{E}$

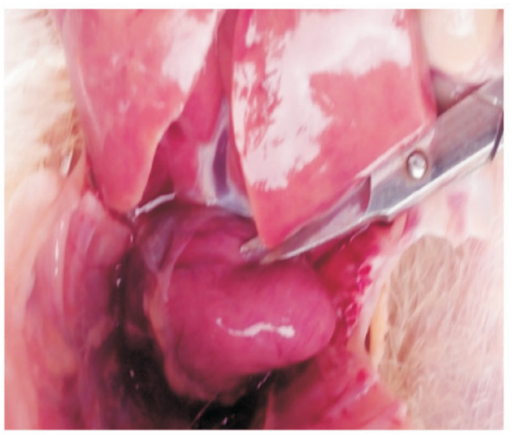

$\mathrm{F}$

Fig. 6. Photomicrographs showing liver lesions different groups 
No significant differences were observed between groups A, E, and F at the end of the $1^{\text {st }}, 3^{\text {rd }}$ and $4^{\text {th }}$ weeks, whereas significant differences were noted for group B when compared to all the other groups at the end of the $5^{\text {th }}$ and $6^{\text {th }}$ weeks. The relative weights of the bursa of fabricius for group B were lower than the chicks in the other groups.

\section{Blood biochemistry of broilers}

Serum alanine transferase and alkaline phosphatase. The serum levels of certain enzymes, such as alanine transferase (ALT) and alkaline phosphatase (ALP), are the biochemical parameters that indicate injury or impairment to the liver.

Serum creatinine and urea. The mean values of serum creatinine and urea in group B were significantly higher than in groups A (negative control), D, E, and F throughout the experimental period. The differences between creatinine and urea levels of groups A, E, and $\mathrm{F}$ were non-significant throughout the experimental period.

Serum albumen, total proteins and globulin. There were no significant differences in the levels of serum albumen, total proteins and globulin of broiler chicks in groups A, E and $\mathrm{F}$ up to the end of the experimental period. However, for group $\mathrm{C}$, these parameters were significantly different from those of groups A, E, and F throughout the experiment. In the case of group $\mathrm{B}$, the differences were more significant when compared with groups $\mathrm{D}, \mathrm{E}$, and $\mathrm{F}$.

Clinical signs and behavior. Normal behavior was observed in group A chicks. All chicks in group A showed alertness when their cages were tapped. Their feces were also normal and semisolid. Besides, they were also attracted towards water and feed with normal frequency. On the other hand, abnormal behaviors and signs were shown by birds in group B. In the initial two weeks a mild type of behavioral alterations and clinical signs were observed which, however, were severe at the end of the experimental period (less feed intake, depression, increased water intake and watery feces with irregular frequency). The experimental birds in group $\mathrm{C}$ showed alertness when their cage was tapped. Stool consistency was also normal during the first week of the experiment. However, abnormalities in behavior and clinical signs appeared during the $2^{\text {nd }}$ week and were severe at the end of the experiment. Chicks in groups D, E, and F showed normal signs and behavior, like group A (negative control group), throughout the experiment.

Rate of mortality. Group B exhibited the highest mortality rate, followed by group C. Maximum casualties were observed at the end of the $6^{\text {th }}$ week. On the other hand, minimum mortality was recorded in groups A and $\mathrm{F}$ ( $4 \%$ only). Amongst the adsorbent treated groups, there was a decrease in the mortality rate with the increase in adsorbent dosage. The percentage mortality rates were $4,30,17,8,5$ and $4 \%$ respectively in groups $\mathrm{A}, \mathrm{B}, \mathrm{C}, \mathrm{D}, \mathrm{E}$, and $\mathrm{F}$ at the end of the experimental period $(\mathrm{B}>\mathrm{C}>\mathrm{D}>\mathrm{E}>\mathrm{A}$ and $\mathrm{F})$. 
M. Zahoor et al.: Ochratoxin A detoxification by highly porous carbon nanocomposites

\section{Discussion}

The XRD pattern of the prepared adsorbent showed diffraction peaks at $20 ; 16.05$, 35.55 and 62.6 corresponding to refractive indices; 111,311 and 440 of $\mathrm{Fe}_{3} \mathrm{O}_{4}$ (KREHULA and MUSIC, 2007). Diffraction peaks at 20;11.85, 19.40, 25.15, 33.15, 40.5, 45.05 and 54.05 correspond to the indices; 020,110, 120, 130, 121, 131 and 221 of goethite (MOHAMMAD et al., 2017)), while the diffraction peaks at 20; 24.2 and 49.5 correspond to indices; 012 and 024 of hematite (KREHULA and MUSIC, 2007).

Energy dispersive X-Ray images showed the presence of iron and oxygen at different $\mathrm{KeV}$. The Fe peaks may be observed at $0.8,6.4$ and $7 \mathrm{KeV}$ in the photographs, whereas oxygen is present at $0.4 \mathrm{KeV}$. Nearly the same spectral data were reported by MOHAMMAD et al. (2017).

The TG/DTA photograph shows that there was no weight loss of the sample up to 390 ${ }^{\circ} \mathrm{C}$. However, a rapid loss in weight may be observed from 420 to $560{ }^{\circ} \mathrm{C}$. The mass loss from 390 to $420{ }^{\circ} \mathrm{C}$ was slow, whereas beyond $420{ }^{\circ} \mathrm{C}$, a sudden fall in mass occurred. The observed mass loss may be attributed to evaporation of water molecules present in the sample and conversion of impurities/carbonaceous material into oxides. No farther loss of mass was recorded after $560{ }^{\circ} \mathrm{C}$. Endothermic and exothermic peaks may also be seen in the DTA curve (Fig. 2).

The FTIR spectra shows peaks at 3380 and $2660 \mathrm{~cm}-1$ which represents $\mathrm{O}-\mathrm{H}$ stretching vibration and aliphatic $\mathrm{C}-\mathrm{H}$ respectively. The band of $\mathrm{C}=\mathrm{O}$ and $\mathrm{C}=\mathrm{C}$ may be observed at 1200 and $1000 \mathrm{~cm}-1$ respectively (WAN et al., 2013). The peak at 1004.91 and 1180 cm-1 may be attributed to stretching of C-O bond (HADI et al., 2015), whereas the peak at $595 \mathrm{~cm}-1$ corresponds to stretching of Fe-O (SNEHA and SUNDARAM, 2015).

The genotoxic effect of OTA has been reported by several authors (PFOHLLESZKOWICZ and MANDERVILLE, 2012). In the present study, groups C, D, E, and F were fed with ochratoxin A contaminated feed (400 $\mu \mathrm{g}$ OTA $/ \mathrm{kg}$ ) supplemented with $0.3,0.6,0.9$ and $1.2 \%(\mathrm{w} / \mathrm{w})$ of the prepared adsorbents respectively. The total comet score and genotoxicity in the blood, kidney and liver samples of groups $\mathrm{C}$ and D were comparatively lower than group B, while group F showed the lowest total comet score, followed by group $\mathrm{E}$ (adsorbent treated groups). In groups $\mathrm{E}$ and $\mathrm{F}$ (highest adsorbent doses treated groups) no genotoxic effects were observed, which may be correlated with the fact that maximum ochratoxin A was adsorbed by the adsorbent, and was not available to cause any injurious effects in the chicks in these groups. The prepared adsorbent is thus able to ameliorate the toxic effects of ochratoxin A in broiler chickens, if given as a dietary supplement in their feed.

The pathological changes observed in the kidney sections of broilers exposed to OTA contaminated feed resulted in congestion, and necrotic and degenerative changes 
in the renal tubular epithelial cells. These alterations were much more prominent in the positive control group (ochratoxin mixed feed without adsorbent). Similar results have been observed by various workers in birds (STOEV et al., 2000). Kidney sections of birds suffering from experimental ochratoxicosis have shown mononuclear cell infiltration around the blood vessels, degenerative changes in the renal corpuscles, and proliferation of epithelial cells (OBRIEN et al., 2001).

These pathological changes were reduced to a great extent in the kidney and liver samples of adsorbent treated groups, particularly groups $\mathrm{E}$ and $\mathrm{F}$, indicating that most of the ochratoxin had been adsorbed by the prepared adsorbents in the intestinal tract of chicks.

Swollen, bulging kidneys with pinpoint lesions were described by SAWALE et al (2009) in laying hens, and in broiler chicks by KUMAR et al. (2004). Other workers also reported swollen kidneys and liver with pinpoint hemorrhages in laying hens and broiler chicks (POLITIS et al., 2010). Gross lesions on different organs in broiler chicks in ochratoxicosis have also been reported (SAWALE et al., 2009). In our experiments the reduction in lesion formation and morphological alterations were due to the adsorption of OTA by the prepared absorbent.

A reduction in the body weight of chicks when exposed to ochratoxin A contaminated feed has already been reported (OBRIEN et al., 2001). Our study showed that the body weight of chicks in group B decreased throughout the course of the study. The food conversion ratio (FCR) of group B was also impaired, whereas those groups receiving ochratoxin A contaminated feed along with different levels of adsorbent, showed increases in body weight and normal FCR. The reduction in the weight of chicks in group B may be due to their lower attraction to their feed. These results are in line with the report by HANIF et al., (2006). They observed a reduction in weight due to low feed ingestion that hampered protein synthesis, since OTA acts as a competitive inhibitor of phenylalanine, thus preventing the attachment of this specific amino acid to the phenylalanine transfer RNA synthetase enzyme. On the other hand, chicks in groups $\mathrm{E}$ and $\mathrm{F}$ showed a normal increase in body weight and normal FCR, just like that of group A (negative control), suggesting that the prepared adsorbent had ameliorated the toxic effects of ochratoxin A.

The increase in weight of the kidneys and liver might be associated with accumulation of OTA since the liver is the store house of the body, and the kidneys eliminate toxic substances from the body. The toxic effects of OTA impaired their ability to eliminate these toxins, which resulted in accumulation of OTA in these organs. Similar alterations in the liver have already been reported in different avian species (STOEV et al., 2002; TURESKY, 2005; HANIF et al., 2006). Our observations support the earlier reports about an increase in the weight of the livers of chicks fed OTA contaminated feed. 
The ALT and ALP serum levels in groups B and C were higher than those in groups D, E, and F. According to ELAROUSSI et al. (2006), a significant increase in serum ALT concentration may be observed when the birds are fed with ochratoxin A contaminated feed.

Our findings are in line with the results of SAWALE et al. (2009) for white leghorn and broilers. Significantly increased levels of serum creatinine and urea in the OTA treated group, in addition to histological changes, also confirm impaired renal function and the primary site of action of OTA. The present results show that the addition of adsorbent to ochratoxin A contaminated feed strongly ameliorated the toxic effects of ochratoxin A in experimental chicks.

Usually, the serum albumen, total proteins and globulin levels decrease when chicks are fed with ochratoxin contaminated feed (KUBINA et al., 1990). In our study no significant differences were observed between chicks in the negative control group and those fed on diets containing ochratoxin A plus adsorbent. Similar findings have also been reported previously by WAN et al. (2013).

Different clinical signs and behavioral alterations in poultry chicks (during ochratoxicosis) have been reported previously. Ochratoxin toxicity in broilers results in an increase in water intake and a decrease in feed consumption (ELAROUSSI et al., 2006). Low feed intake and maximum attraction to water in chickens is an adaptation to avoid dehydration and to replace water contents that have been lost along with watery feces. Decreased attraction to feed and increased attraction to water have also been reported in layers, turkeys and poultry chicks in ochratoxicosis (SAWALE et al., 2009). According to our results, diarrhea (watery stools), attraction to water intake, and depression were some noticeable signs displayed by the broilers fed with ochratoxin A contaminated feed. Such findings have also been reported by KOYNARSKI et al. (2007) in chickens and laying hens fed with different dietary levels of ochratoxin. In the present study, abnormal signs and behavior was shown by the birds in the positive control group, fed with ochratoxin A contaminated feed (without mixing adsorbent) throughout the experiment. This shows that the prepared adsorbent had the capability to detoxify the toxic effects of ochratoxin A in broiler chicks.

Increased mortality rates with an increase in ochratoxin exposure over a long time period and a dietary OTA dose in broilers have also been reported in poultry birds (STOEV et al., 2000) which is in line with conclusions drawn by AFZAL et al. (1979) from their study. According to them, the highest percentage of mortality can be observed in chickens when they are exposed to different dietary levels of mycotoxin contaminated feed. However, the lowest mortality was observed amongst groups fed with mycotoxin contaminated feed along with different levels of adsorbents. 


\section{Conclusions}

Relative analysis of the clinical signs and pathological alterations in the positive and negative control groups showed that the chickens in the positive control group were most severely affected. Amongst the adsorbent treated groups, groups $\mathrm{E}$ and $\mathrm{F}$ showed normal behavior and blood biochemistry, and well-maintained histological structure, like that of the negative control group. From the results it was concluded that the prepared adsorbent can effectively ameliorate the toxic effects of ochratoxin A in Gallus gallus domesticus.

\section{References}

AFZAL, M., R. A. CHEEMA, R. A. CHOUDHARY (1979): Incidence of aflatoxins and aflatoxins producing fungi in animal feedstuffs. Mycopathologia 69, 149-151.

DOI: $10.1007 / \mathrm{bf} 00452826$

COLLINS, A. R. (2004): The comet assay for DNA damage and repair. Mol. Biotech. 26, 249-261. DOI: $10.1385 / \mathrm{mb}: 26: 3: 249$

ELAROUSSI, M. A., F. R. MOHAMED, E. M. BARKOUKY, A. M. ATTA, A. M. ABDOU, M. H. HATAB (2006): Experimental ochratoxicosis in broiler chickens. Avian Pathol. 35, 263-269. DOI: $10.1080 / 03079450600817115$

FINK-GREMMELS, J. (2004): Quality objectives in animal nutrition. In: World Nutrition Forum. Biomin FGmbtt, Austria, pp. 49-50.

GULFAM, N., M. KHISROON, M. ZAHOOR, F. A. KHAN (2018): Development of highly porous carbon nanocomposites derived from coconut shell and its in vitro efficacy of ochratoxin A detoxification. Des. Water Treat. 105, 216-225.

DOI: $10.5004 /$ dwt.2018.22016

HADI, P., M. XU, C. NING, C. S. K. LIN, G. McKAY (2015): A critical review on preparation, characterization and utilization of sludge-derived activated carbons for wastewater treatment. Chem. Eng. J. 260, 895-906.

DOI: $10.1016 /$ j.cej.2014.08.088

HANIF, N. Q., M. NASEEM, S. KHATOON, N. MALIK (2006): Prevalence of mycotoxins in poultry rations. Pak. J. Sci. Indust. Res. 49, 120-124.

IBRAHIM, I. K., A. M. SHAREEF, K. M. T. AL-JOUBORY (2000): Ameliorative effects of sodium bentonite on phagocytosis and Newcastle disease antibody formation in broiler chickens during aflatoxicosis. Res. Vet. Sci. 69, 119-123.

DOI: $10.1053 /$ rvsc. 2000.0390

ISAHAK, W. N. R. W., M. W. M. HISHAM, M. A. YARMO (2013): Highly porous carbon materials from biomass by chemical and carbonization method: a comparison study. J. Chem. 2013, 1-6. DOI: 10.1155/2013/620346 
M. Zahoor et al.: Ochratoxin A detoxification by highly porous carbon nanocomposites

KHAN, F. A., M. ZAHOOR (2014): In vivo detoxification of aflatoxin B1 by magnetic carbon nanostructures prepared from bagasse. BMC Vet. Res. 10, 255.

DOI: 10.1186/s12917-014-0255-y

KOYNARSKI, V., S. STOEV, N. GROZEVA, T. MIRTCHEVA, H. DASKALOV, J. MITEV, P. MANTLE (2007): Experimental coccidiosis provoked by Eimeria acervulina in chicks simultaneously fed on ochratoxin A contaminated diet. Res. Vet. Sci. 82, 225-231.

DOI: $10.1016 /$ j.rvsc.2006.07.004

KREHULA, S., S. MUSIC (2007): Formation of magnetite in highly alkaline media in the presence of small amounts of ruthenium. Croatica Chemica Acta 80, 517-527.

KUBINA, L. F., R. B. HARVEY, W. E. HUFF, D. E. CORRIER, T. D. PHILliPS, G. E. ROTTINGHAUS (1990): Efficacy of hydrated sodium calcium aluminosilicate to reduce the toxicity of aflatoxins and T-2 toxin. Poult. Sci. 69, 1078-1086.

DOI: $10.3382 / \mathrm{ps} .0691078$

KUIPER-GOODMAN, T., P. M. SCOTT (1989): Risk assessment of the mycotoxin ochratoxin A. Biomed. Environ. Sci. 2, 179-248.

KUMAR, A., N. JINDAL, C. L. SHUKLA R. K. ASRANI, D. R. LEDOUX, G. E. ROTTINGHAUS (2004): Pathological changes in broiler chickens fed ochratoxin A and inoculated with Escherichia coli. Avian Pathol. 33, 413-417.

DOI: $10.1080 / 03079450410001724021$

LUNA, L. G. (1968): Manual of histologic staining methods of the Armed Forces, Institute of Pathology, Blakiston Division, McGraw-Hill, New York.

MEDINA, A., M. JIMENEZ, R. MATEO, N. MAGAN (2007): Efficacy of natamycin for control of growth and ochratoxin A production by Aspergillus carbonarius strains under different environmental conditions. J. Appl. Microbiol. 103, 2234-2239.

DOI: $10.1111 / \mathrm{j} .1365-2672.2007 .03462 . \mathrm{x}$

MOHAMMAD, M. K., M. ZAHOOR, M. BAKHTIAR, A. K. FARHAT, U. RIAZ, M. A. S. NASEER (2017): Removal of heavy metal from drinking water by magnetic carbon nanostructures prepared from biomass. J. Nano Mat. 2017, 1-10.

DOI: $10.1155 / 2017 / 5670371$

MURPHY, P. A., S. HENDRICH, C. C. LANDGREN, M. BRYANT (2006): Food mycotoxins: an update. J. Food Sci. 71, 51-65.

OBRIEN, E., A. H. HEUSSNER, D. R. DIETRICH (2001): Species-, Sex-, and cell type-specific effects of ochratoxin A and B. Toxicol. Sci. 63, 256-264.

DOI: $10.1093 /$ toxsci/63.2.256

OGUZ, H., H. H. HADIMLI, V. KURTOGLU, O. ERGANIS (2003): Evaluation of humoral immunity of broilers during chronic aflatoxin (50 and $100 \mathrm{ppb}$ ) and clinoptilolite exposure. Revue Méd. Vét. 154, 483-486. 
ORTATATLI, M., H. OGUS, F. HATIPOGLU, M. KARAMAN (2005): Evaluation of pathological changes in broilers during chronic aflatoxin (50 and $100 \mathrm{ppb})$ and clinoptilolite exposure. Res. Vet. Sci. 78, 61-68.

DOI: 10.1016/j.rvsc.2004.06.006

PFOHL-LESZKOWICZ, A., R. A. MANDERVILLE (2012): An update on direct genotoxicity as a molecular mechanism of ochratoxin a carcinogenicity. Chem. Res. Toxicol. 25, 252-262.

DOI: $10.1021 / \mathrm{tx} 200430 \mathrm{f}$

POLITIS, I., K. FEGEROS, S. NITSCH, G. SCHATZMAYR, D. KANTAS (2010): Use of Trichosporon mycotoxinivorans to suppress the effects of ochratoxicosis on the immune system of broiler chicks. British Poult. Sci. 46, 58-65.

DOI: $10.1080 / 00071660400023904$

SAWALE, G. K., R. C. GOSH, K. RAVIKANTH, S. MAINI, D. S. REKHE (2009): Experimental mycotoxicosis in layer induced by ochratoxin $\mathrm{A}$ and its amelioration with herbomineral toxin binder Toxiroak. Int. J. Poult. Sci. 8, 798-803.

DOI: 10.3923 /ijps.2009.798.803

SCHILTER, B., M. MARIN-KUAN, T. DELATOUR, S. NESTLER, P. MANTLE, C. CAVIN (2005): Ochratoxin A: Potential epigenetic mechanisms of toxicity and carcinogenicity. Food Additive \& Contaminants 22, 88-93.

DOI: $10.1080 / 02652030500309319$

SINGH, G. S., V. S. CHAUHAN, G. I. JHA, K. K. SINGH (1990): Immunosuppression due to chronic ochratoxicosis in broiler chicken. J. Comparative Pathol. 103, 399-410.

DOI: $10.1016 / \mathrm{s} 0021-9975(08) 80028-\mathrm{x}$

SINGH, N. P., M. T. MCCOY, R. R. TICE, E. L. SCHNEIDER (1988): A simple technique for quantitation of low levels of DNA damage in individual cells. Exp. Cell Res. 175, 184-191.

DOI: $10.1016 / 0014-4827(88) 90265-0$

SNEHA, M., N. M. SUNDARAM (2015): Preparation and characterization of an iron oxidehydroxyapatite nanocomposite for potential bone cancer therapy. Int. J. Nanomedicine 2015, 99-106.

DOI: $10.2147 /$ ijn.s79985

STOEV, S. D., D. DJUVINOV, T. MIRTCHEVA, D. PAVLOV, P. MANTLE (2002): Studies on some feed additives giving partial protection against ochratoxin A toxicity in chicks. Toxicol. Lett. 135, 33-50.

DOI: $10.1016 / \mathrm{s} 0378-4274(02) 00234-5$

STOEV, S. D., G. ANGUELOV, I. IVANOV, D. PAVLOV (2000): Influence of ochratoxin A and an extract of artichoke on the vaccinal immunity and health in broiler chicks. Exp. Toxicol. Pathol. 52, 43-55.

DOI: 10.1016/s0940-2993(00)80014-7 
M. Zahoor et al.: Ochratoxin A detoxification by highly porous carbon nanocomposites

TURESKY, R. J. (2005): Ochratoxin A induces oxidative DNA damage in liver and kidney after oral dosing to rats. Mol. Nutrition Food Res. 49, 160-1167.

DOI: $10.1002 / \mathrm{mnfr} .200500124$

ZAHOOR, M., F. A. KHAN (2016): Aflatoxin B1 detoxification by magnetic carbon nanostructures prepared from maize straw. Des. Water Treat. 57, 11893-11903.

DOI: $10.1080 / 19443994.2015 .1046147$

Received: 15 December 2018

Accepted: 16 September 2019

\section{ZAHOOR, M., N. GULFAM, M. KHISROON, F. A. KHAN: Učinkovitost in vivo detoksifikacije ohratoksina A pomoću visokoporoznog nanokompozita ugljika pripravljenog od ostataka šećerne repe. Vet. arhiv 89, 851-872, 2019.}

\section{SAŽETAK}

Cilj je ovoga istraživanja bio razviti visokoporozne nanokompozite ugljika za detoksifikaciju ohratoksina A (OTA) u brojlera. Jednodnevni pilići podijeljeni su u šest skupina (A do F). Skupina A hranjena je čistom hranom. Skupini B davana je hrana kojoj je dodano $400 \mu \mathrm{g} / \mathrm{kg}$ OTA-e, dok su preostale skupine hranjene hranom kojoj je uz $400 \mu \mathrm{g} / \mathrm{kg}$ OTA-e dodane različite razine adsorbensa. Klinički znakovi kod pozitivne kontrole (skupina B), poput depresije, proljeva, povećanog unosa vode, niske tjelesne mase, visoke genotoksičnosti, natečenih i krvavih bubrega i jetre, uspoređeni su s ostalim skupinama. Skupine tretirane adsorbensima pokazale su gotovo normalne kliničke znakove. Skupine $\mathrm{C}$ i D do neke su mjere zahvaćene, dok su skupine $\mathrm{E}$ i $\mathrm{F}$ pokazale neoštećenu DNA, normalno ponašanje, normalne biokemijske krvne pokazatelje i dobro održanu histološku strukturu kao i brojleri u negativnoj kontrolnoj skupini.

Ključne riječi: brojleri; ohratoksin A; adsorbens; biokemijski pokazatelji u krvi; ALT; ALP 